\title{
Miejsce ruksolitynibu w leczeniu chorych na mielofibrozę
}

\section{Place of ruxolitinib in the treatment of patients with myelofibrosis}

\author{
Aleksandra Gołos, Joanna Góra-Tybor \\ Klinika Hematologii, Instytut Hematologii i Transfuzjologii, Warszawa
}

\begin{abstract}
Streszczenie
Ruksolitynib, inhibitor kinazy JAK1/JAK2, jest pierwszym i dotychczas jedynym zarejestrowanym lekiem w leczeniu chorych na mielofibroze (MF). Zmniejsza on wymiary śledziony oraz objawy ogólne choroby, takie jak świqd skóry, poty nocne czy utrata masy ciata. Gtównymi dziataniami niepożadanymi leku sa matoplytkowość i niedokrwistość, a niehematologicznymi - immunosupresja $i$ czestsze wystepowanie infekcji, $w$ tym oportunistycznych. Ruksolitynib jako lek zmniejszajacy śledzione $i$ objawy ogólne choroby można stosować jako pomost przed procedura przeszczepienia allogenicznych krwiotwórczych komórek macierzystych. W Polsce ruksolitynib jest dostęny w ramach programu lekowego dla chorych na MF z grup ryzyka pośredniego-2 i wysokiego z objawowa splenomegalia $i$ objawami ogólnymi.
\end{abstract}

Słowa kluczowe: mielofibroza, inhibitory JAK, ruksolitynib

Hematologia 2018; 9, 2: 90-99

\begin{abstract}
Ruxolitinib, inhibitor JAK1/JAK2 kinases, has been the only drug approved for the treatment of patients with myelofibrosis (MF). It reduces spleen size as well as constitutional symptoms, such as pruritus, night sweats, and weight loss. The main adverse events of the drug are thrombocytopenia and anemia. Non-hematologic side effects results from immunosuppression: increased risk of infections, including opportunistic ones. Ruxolitinib may be indicated before transplantation of allogeneic hematopoietic stem cells due to its effect on constitutional symptoms and reduction of spleen size. In Poland ruxolitinib has been approved for patients with intermediate-2 and high-risk MF.
\end{abstract}

Key words: myelofibrosis, JAK inhibitors, ruxolitinib

Hematologia 2018; 9, 2: 90-99

\section{Wprowadzenie}

Ruksolitynib, inhibitor kinazy JAK1/JAK2 (Janus kinase 1/2), jest pierwszym i dotychczas jedynym zarejestrowanym lekiem w leczeniu chorych na nowotwór mieloproliferacyjny - mielofibrozę (MF, myelofibrosis). Lek zostal dopuszczony przez Agencję ds. Żywności i Leków (FDA, Food and Drug Administration) w 2011 roku do leczenia pacjentów $\mathrm{z} \mathrm{MF} z$ grup pośredniego i wysokiego ryzyka według
Międzynarodowego Wskaźnika Prognostycznego (IPSS, International Prognostic Scoring System) [1]. W 2012 roku Europejska Agencja Leków (EMA, European Medicines Agency) zarejestrowała ruksolitynib do leczenia chorych na MF $z$ towarzysząca splenomegalią i/lub objawami ogólnymi [2]. Podstawą uzyskania rejestracji były wyniki dwóch randomizowanych badań III fazy - COMFORT-I (skuteczność ruksolitynibu $v$. placebo) oraz COMFORT-II (ruksolitynib $v$. najlepsza dostępna terapia). 
Od 1 stycznia 2017 roku w Polsce jest dostępny program lekowy leczenia chorych na pierwotną i wtórną MF ruksolitynibem. Do terapii kwalifikują się chorzy obciążeni ryzykiem pośrednim-2 i wysokim, ze splenomegalią $(\geq 5 \mathrm{~cm}$ pod lukiem żebrowym w badaniu palpacyjnym oraz ultrasonograficznym) i objawami ogólnymi. Do oceny nasilenia objawów ogólnych konieczne jest zastosowanie formularza MPN-SAF TSS (Myeloproliferative Neoplasm Symptom Assessment Form Total Symptom Score), w którym są uwzględnione następujące objawy ogólne: zmęczenie, szybkie uczucie sytości po posiłku, dyskomfort w jamie brzusznej, zmniejszona aktywność i koncentracja, poty nocne, świąd, ból kości, gorączka, niezamierzona utrata masy ciała [3].

Pierwotna mielofibroza (PMF, primary myelofibrosis) jest chorobą klonalną, w której dochodzi do proliferacji atypowych megakariocytów. Przyczyna MF pozostaje nieznana. Za czynnik bezpośrednio odpowiedzialny za rozwój choroby uważa się somatyczną mutację wielopotencjalnej komórki pnia wraz z uszkodzeniem mikrośrodowiska szpiku kostnego, tak zwanej niszy hematopoetycznej [4]. Kluczowa w patogenezie MF jest deregulacja szlaku sygnałowego JAK-STAT (signal transduceres and activators of transcription) [5]. U 50-60\% chorych występuje mutacja genu kinazy tyrozynowej $J A K 2 \mathrm{~V} 617 \mathrm{~F}$ w eksonie 14 [6]. U około $10 \%$ chorych $\mathrm{z}$ niezmutowanym genem JAK2 (wtJAK2, wild-type $J A K 2$ ) obecna jest mutacja genu $M P L$ W $515 \mathrm{~L} / \mathrm{K}$ w receptorze dla trombopoetyny (TPO), zaś u około $80 \%$ chorych bez wyżej wymienionych aberracji stwierdza się mutację w genie kalretikuliny (CALR, calreticulin [7, 8]. U 10-12\% chorych nie wykrywa się żadnej $z$ tych trzech mutacji [9]. Ta grupa charakteryzuje się najpoważniejszym rokowaniem, z szybszą progresją choroby, częstszą transformacją do ostrej białaczki i krótszym czasem przeżycia całkowitego (OS, overall survival) [9]. Kinaza JAK2 odgrywa kluczową rolę w regulacji proliferacji i różnicowania prekursorów poszczególnych linii komórkowych jako wewnątrzkomórkowy przekaźnik sygnału pochodzącego $z$ czynników stymulujących hematopoezę, między innymi erytropoetyny, czynnika wzrostu granulocytów, TPO oraz innych cytokin [10]. Wszystkie trzy mutacje powodują konstytutywną aktywację szlaku JAK-STAT.

W wyniku wymienionych wyżej mutacji u pacjentów $z$ MF dochodzi do zwiększonego wydzielania cytokin prozapalnych: interleukin $8,10,15$, czynnika martwicy nowotworów alfa (TNF $\alpha$, tumor necrosis factor alpha), oraz czynników wzrostu, takich jak naczyniowo-śródbłonkowy czynnik wzrostu (VEGF, vascular endothelial growth factor), zasadowy czynnik wzrostu fibroblastów (bFGF, basic fibroblast growth factor), płytkopochodny czynnik wzrostu (PDGF, platelet-derived growth factor) oraz transformujący czynnik wzrostu beta (TGF $\beta$, transforming growth factor beta). W wyniku ich działania dochodzi do nasilenia włóknienia, uruchomienia pozaszpikowej hematopoezy, stymulacji angiogenezy i zwiększenia katabolizmu [4].

W patogenezie PMF istotną rolę odgrywają mutacje genów zaangażowanych w mechanizmy epigenetyczne. Należą do nich mutacje genów biorących udział $\mathrm{w}$ procesach potranslacyjnej modyfikacji histonów (ASXL1 o częstości $10-35 \%$, EZH2 o częstości 7-10\%), metylacji DNA (TET2, DNMT3A, IDH1/2), splicingu mRNA (SRFS2, $S R F 3 B 1)$ oraz procesach naprawy DNA (TP53). Stwierdzono, że obecność przynajmniej jednej mutacji spośród ASXL1, EZH2, SRSF2, IDH1/2 determinuje tak zwane wysokie ryzyko molekularne (HMR, high-molecular risk), wiąże się z krótszym OS i wyższym ryzkiem transformacji blastycznej [11].

Głównymi objawami u chorych są splenomegalia (85-100\% chorych) oraz stymulowane przez cytokiny objawy ogólne. Śledziona osiąga znaczne rozmiary; niekiedy sięga prawego dołu biodrowego, powoduje bóle brzucha, szybkie uczucie pełności po jedzeniu, biegunkę, obrzęki kończyn dolnych. Do najczęstszych objawów ogólnych należą chudnięcie, poty nocne, zmęczenie, gorączka, uporczywy świąd skóry. W momencie rozpoznania MF objawy występują u ponad połowy chorych.

\section{Mechanizm dzialania ruksolitynibu}

W ludzkim genomie są zakodowane cztery kinazy Janusowe: JAK1, JAK2, JAK3, TYK2. Nazwa pochodzi od imienia rzymskiego boga Janusa, który miał dwie twarze. Kinazy JAK mają dwie domeny białkowe o odmiennym działaniu — jedną, katalitycznie aktywną domenę na C-końcu i drugą pseudokinazową, która przyłącza adenozynotrifosforan (ATP, adenosine triphosphate), ale nie fosforyluje substratów [10]. Kinaza JAK2 przyłącza się do trzech receptorów: dla erytropoetyny (EPOR, erythropoietin receptor), trombopoetyny (MPL), dla czynnika wzrostu granulocytów (G-CSF, granulocyte-colony stimulating factor receptor), powodując ich dimeryzację i aktywację [12].

Cytokiny, wiążąc się do zewnątrzkomórkowej domeny receptora, powodują zmianę jego konformacji, która $z$ kolei umożliwia dimeryzację przyłączonej kinazy JAK2, a następnie krzyżową 
fosforylację dimerów. To rozpoczyna proces kaskadowej fosforylacji kinaz szlaku STAT i RAS, które uruchamiają transkrypcję genów odpowiedzialnych za proliferację, różnicowanie i przeżycie komórek [10]. Dwie nabyte, patogenne w MF, mutacje w genie JAK2 - V617F i mutacja w eksonie 12 - znajdują się poza aktywną katalitycznie domeną, w obszarze pseudokinazy [13].

Ruksolitynib należy do blokerów kinaz JAK typu I. Inhibitory te przyłączają się do JAK w jej aktywnej konformacji, w miejscu domeny kinazowej [14]. Ruksolitynib najsilniej blokuje JAK2, słabiej JAK1 i JAK3 [14]. Blokada domeny katalitycznej powoduje zwiększoną fosforylację pętli aktywacyjnej w miejscu Y1007, która umożliwia tworzenie heterodimerów $z$ innymi kinazami JAK i wznowienie aktywności katalitycznej [15]. Ten proces może być przyczyną oporności na ruksolitynib w przypadku braku ewolucji klonalnej choroby [16].

\section{Właściwości farmakokinetyczne i farmakodynamiczne}

Ruksolitynibjest cząsteczką o masie 404,36 kDa. Jest rozpuszczalny zarówno w kwaśnym, jak i zasadowym $\mathrm{pH}$. Postacią farmakologiczną są tabletki zawierające 5, 10, 15 lub $20 \mathrm{mg}$ substancji czynnej, które zachowują stabilność w temperaturach $20-25^{\circ} \mathrm{C}[1]$.

Pojedyncza dawka ruksolitynibu podana doustnie szybko się wchłania, osiągając maksymalne stężenie w surowicy po około 2 godzinach [17]. Siła działania leku zwiększa się wraz $\mathrm{z}$ dawką w zakresie 5-200 mg. Na biodostępność ruksolitynibu nie wpływało spożywanie jedzenia, jednak w przypadku wysokotłuszczowych posiłków lek wchłaniał się wolniej [17]. Okres półtrwania ruksolitynibu wynosi około 3 godzin, dlatego zaleca się go dawkować 2 razy/dobę [17].

Ruksolitynib jest metabolizowany przez cytochrom CYP3A4, w mniejszym stopniu przez CYP2C9. Flukonazol, silny inhibitor obu cytochromów, zwiększał stężenie ruksolitynibu w surowicy o 100-300\% [18]. $Z$ tego powodu zaleca się zmniejszenie dawki tego leku o około $50 \%$ z zachowaniem częstości dawek w przypadku konieczności stosowania leków silnie blokujących CYP3A4 (leków przeciwwirusowych, m.in. boceprewiru, rytonawiru, nelfinawiru, leków przeciwgrzybiczych: ketokonazolu, itrakonazolu, posakonazolu, worikonazolu czy antybiotyków - klarytromycyny). Pacjenci powinni być ściśle monitorowani pod kątem występowania toksyczności hematologicznej [1]. U zdrowych ochotników otrzymujących ruksolitynib w dawce $50 \mathrm{mg}$, po przyjęciu silnego induktora CYP3A4 — ryfampicyny, pole pod krzywą ruksolitynibu było o $70 \%$ mniejsze w porównaniu ze stosowaniem tego leku w monoterapii [18]. Chorzy przyjmujący jednocześnie ruksolitynib i leki będące induktorami cytochromu CYP3A4 (m.in. karbamazepina, fenobarbital, fenytoina, ryfampicyna, ziele dziurawca) powinni być częściej monitorowani, a dawkę leku można stopniowo zwiększać $z$ uwzględnieniem bezpieczeństwa stosowania i skuteczności. Nie ma konieczności dostosowywania dawki ruksolitynibu w skojarzeniu $z$ lagodnymi i umiarkowanymi induktorami CYP3A4 (ciprofloksacyna, erytromycyna, diltiazem, cymetydyna, atanazawir, amprenawir) [1]. Lek jest wydalany przez nerki, w mniejszym stopniu przez przewód pokarmowy. U chorych $z$ ciężką niewydolnością nerek początkową dawkę leku należy zmniejszyć, zaś u chorych dializowanych stosować pojedynczą dawkę dobową po zabiegu [1]. W przypadku zaburzeń czynności wątroby początkową dawkę leku należy zmniejszyć o 50\% [1].

\section{Ruksolitynib w badaniach klinicznych}

\section{Badania I i II fazy}

Pierwszym badaniem służącym ocenie skuteczności i bezpieczeństwa ruksolitynibu u chorych z MF było badanie Verstovsek i wsp. [19], którym objęto 153 chorych w zaawansowanych stadiach MF pierwotnej i wtórnej do nadpłytkowości samoistnej lub czerwienicy prawdziwej (PV, polycythemia vera). Maksymalnie tolerowanymi dawkami, limitowanymi przede wszystkim przez małopłytkowość, były 2 razy $25 \mathrm{mg}$ lub $1 \mathrm{raz} 100 \mathrm{mg}$. Dawkę 2 razy $15 \mathrm{mg}$ cechował w tym badaniu najlepszy stosunek korzyści do ryzyka [19]. Przy takim dawkowaniu 17 z 32 chorych (52\%) uzyskało 50-procentowe zmniejszenie śledziony. Po roku efekt utrzymał się u 72\% z tych osób [19]. Oprócz objawów związanych ze splenomegalią ruksolitynib był skuteczny w zmniejszaniu objawów konstytutywnych. Po trwającej 6 miesięcy kuracji u ponad 80\% chorych obserwowano zmniejszenie potów nocnych i świądu skóry o $50 \%$, zaś u $55 \%$ i $40 \%$, odpowiednio, dyskomfortu w jamie brzusznej i bólów kostno-mięśniowych [19]. Po 5-letniej obserwacji u 35\% chorych włóknienie w szpiku kostnym zmniejszyło się, a u $42 \%$ chorych pozostawało niezmienione w stosunku do wyjściowego [20]. W innej analizie, dotyczącej 68 chorych z zaawansowaną MF i różnie nasilonym włóknieniem szpiku (1. stopień - 22\%, 2. stopień $-53 \%$, 3. stopień $-25 \%$ ), oceniano włóknienie po terapii ruksolitynibem (mediana 
czasu leczenia 30,5 mies.) [21]. Grupę kontrolną stanowiło 192 chorych poddanych najlepszej dostępnej terapii (BAT, best available treatment). U 35\% chorych leczonych ruksolitynibem doszło do pogorszenia stopnia włóknienia, natomiast u 58\% chorych pozostało ono niezmienione po 24 miesiącach. W dalszej obserwacji w $1 / 3$ przypadków nastąpiła redukcja stopnia włóknienia. Ograniczenie włóknienia korelowało dodatnio ze zmniejszeniem objętości śledziony. W grupie poddanej BAT istotnie rzadziej opisywano stabilizację, zaś częściej progresję włóknienia szpiku [21].

\section{Badania III fazy}

Randomizowane, przeprowadzone metodą podwójnie ślepej próby badanie COMFORT-I służyło porównaniu skuteczności ruksolitynibu oraz placebo u 309 pacjentów w MF z grupy pośredniego-2 i wysokiego ryzyka, z liczbą płytek krwi (PLT, platelets) przekraczającą 100 G/1 [22]. Dawka początkowa ruksolitynibu wynosiła $15 \mathrm{mg}$ 2 razy/dobę, gdy liczba PLT wynosiła 100-200 G/1 oraz, $20 \mathrm{mg} 2 \mathrm{razy} /$ dobę przy liczbie PLT ponad 200 G/l. Pierwszorzędowym punktem końcowym był odsetek chorych, którzy po 6 miesiącach leczenia osiągnęli 35-procentową redukcję objętości śledziony w badaniach rezonansu magnetycznego (MRI, magnetic resonance imaging) lub tomografii komputerowej (CT, computed tomography) w stosunku do jej wyjściowych wymiarów. Wielkość ta odpowiada zmniejszeniu o około $50 \%$ splenomegalii $\mathrm{w}$ badaniu przedmiotowym [23]. W grupie leczonej ruksolitynibem $41,9 \%$ chorych osiagnęło założenia pierwotnego punktu końcowego. W grupie przyjmującej placebo odsetek ten wyniósł $0,7 \%(\mathrm{p}<0,001)$. U 102 z 153 chorych $z$ grupy otrzymującej placebo $(66,7 \%)$ obserwowano powiększenie śledziony, zaś tylko u około $10 \%$ - stabilizację [24].

Drugorzędowymi punktami końcowymi były trwałość odpowiedzi, ograniczenie objawów ogólnych i OS. U około $2 / 3$ chorych po 12 miesiącach leczenia ruksolitynibem utrzymywała się zmniejszona objętość śledziony. Około połowy pacjentów leczonych ruksolitynibem uzyskało 50-procentowe ograniczenie objawów ogólnych po 6 miesiącach leczenia w porównaniu z 5,3\% chorych $z$ grupy otrzymującej placebo $(p<0,01)[22,25]$. W ocenie objawów konstytutywnych posługiwano się kwestionariuszem objawów MF (Myelofibrosis Symptoms Assessment Form). Obserwowano również poprawę jakości życia ocenianą za pomocą kwestionariusza QLQ-30 (EORTC QLQ-C30, European Organisation for Research and Treatment of Cancer Quality of Life 30 Questionnaire). Poprawę jakości życia oraz ograniczenie objawów ogólnych obserwowano również u chorych, u których nie doszło do zmniejszenia wymiarów śledziony lub było ono minimalne ( $<10 \%$ wyjściowych wymiarów) [25]. Trzech chorych leczonych ruksolitynibem $(1,9 \%)$ i $12(7,8 \%)$ $z$ grupy przyjmującej placebo nie ukończyło badania $z$ powodu progresji choroby [22]. Ryzyko zgonu po 51 tygodniach obserwacji było większe w grupie przyjmującej placebo $(15,7 \%$ chorych) niż w grupie leczonej ruksolitynibem $(8,4 \%$, współczynnik ryzy$\mathrm{ka}$ [HR, hazard ratio] 0,50; $\mathrm{p}=0,04)$ [22]. W analizie 3-letniej utrzymywał się trend w kierunku dłuższego przeżycia chorych pierwotnie objętych randomizacją do grupy leczonej ruksolitynibem w porównaniu $z$ grupą otrzymującą placebo (HR $0,69 ; \mathrm{p}=0,067)[26]$.

W badaniu COMFORT-II, w którym oceniano skuteczność ruksolitynibu w porównaniu z BAT, wzięło udział 219 pacjentów, w tym 146 leczonych ruksolitynibem i 73 poddanych BAT [27]. U około $40 \%$ chorych w obu grupach stwierdzono pośredni-2 stopień ryzyka choroby, a u pozostałych chorych - wysoki. Początkowe dawki ruksolitynibu ustalono na podstawie liczby PLT i wynosity one 2 razy $15 \mathrm{mg} \mathrm{u} 38 \%$ i 2 razy $20 \mathrm{mg}$ u $62 \%$ badanych. W grupie poddanej BAT najczęściej stosowano hydroksykarbamid (47\% chorych), leczenie objawowe (33\%) i glikokortykosteroidy (16\%). Pierwotny punkt końcowy, jakim była 35-procentowa redukcja objętości śledziony, w 48. tygodniu leczenia osiągnęło $28 \%$ chorych w grupie leczonej ruksolitynibem i $0 \% \mathrm{w}$ grupie poddanej BAT $(\mathrm{p}<0,001)$ [27]. Mediana czasu trwania odpowiedzi u chorych leczonych ruksolitynibem nie została osiągnięta. U 80\% chorych $z$ tej grupy odpowiedź utrzymywała się po 12 miesiącach obserwacji. Podobnie jak w badaniu COMFORT-I u pacjentów leczonych ruksolitynibem objawy konstytutywne były istotnie mniej nasilone, a jakość życia tych osób była lepsza niż w grupie poddanej BAT [27, 28]. W odniesieniu do OS wykazano przewage ruksolitynibu nad BAT (HR 0,70, 95-proc. przedział ufności [CI, confidence interval] 0,20-2,49). Trzyletnia aktualizacja potwierdziła te obserwacje $(\mathrm{HR}=0,48 ; \mathrm{p}=0,009)$ [29]. Łączna analiza OS po 3 latach w obu badaniach COMFORT wykazała 35-procentowe obniżenie ryzyka zgonu $\mathrm{w}$ grupie leczonej ruksolitynibem w porównaniu z BAT lub placebo ( $\mathrm{HR}=0,65,95 \%$ CI 0,46-0,90; $\mathrm{p}=0,01)[30]$. Należy jednak podkreślić, że ocena OS nie była celem pierwszorzędowym obu badań COMFORT - obejmują one stosunkowo niewielkie grupy chorych i nie mają wystarczającej mocy statystycznej do wiarygodnej oceny 
tego parametru [22, 27]. Dodatkowo ocenę wpływu ruksolitynibu na OS utrudnia przejście większości pacjentów z grupy otrzymującej placebo/ /poddanej BAT do grupy przyjmującej badany lek. $Z$ tego względu eksperci zalecają stosowanie ruksolitynibu $z$ intencją zmniejszenia śledziony i objawów ogólnych choroby. Natomiast podkreślają, że nie ma wystarczających danych, aby lek włączano jako wykazujący wpływ na przedłużenie OS [31-34].

W obu badaniach COMFORT dowiedziono skuteczności ruksolitynibu w redukcji objętości śledziony i objawów konstytutywnych zarówno $\mathrm{u}$ chorych $\mathrm{z}$ mutacją V617F, jak i bez niej $[22,27]$. Aktywność ruksolitynibu w obu grupach chorych potwierdza, że głównym patogenetycznym mechanizmem w MF jest nadmierna aktywacja szlaku JAK-STAT, niezależnie od prowadzących do niej mutacji $[35,36]$.

\section{Inne badania kliniczne}

W retrospektywnym badaniu grupy włoskiej dotyczącym 408 chorych leczonych ruksolitynibem oceniano wpływ wyjściowych parametrów laboratoryjnych i klinicznych na odpowiedź na leczenie pod postacią zmniejszenia śledziony [37]. W analizie wielowariantowej wykazano, że choroba w stopniach ryzyka pośrednim-2 i wysokim, znaczna splenomegalia i zależność od przetoczeń ujemnie korelowały $z$ redukcją rozmiarów śledziony (odpowiednio $\mathrm{p}=0,024$, $\mathrm{p}=0,017 \mathrm{i} \mathrm{p}=0,022$ ). Istotna okazała się również dawka leku — im była większa w pierwszych 12 tygodniach leczenia, ( $\geq 10 \mathrm{mg}$ ), tym u wyższego odsetka chorych obserwowano zmniejszenie śledziony $(\mathrm{p}=0,019)$. Podobnie liczba PLT poniżej $200 \mathrm{G} / 1$ również ograniczała szansę na odpowiedź $(\mathrm{p}=0,028)$. Ponadto wykazano, że czas trwania choroby wynoszący co najmniej 2 lata przed włączeniem leczenia istotnie zmniejsza szansę na odpowiedź ( $\mathrm{p}=0,048)$, co może się wiązać $Z$ wyższym stopniem zaawansowania choroby [37].

W analizie Pieri i wsp. [38] oceniono skuteczność i bezpieczeństwo ruksolitynibu u 21 chorych (MF-12, PV - 5, pierwotna małopłytkowość samoistna - 4), u których doszło do zakrzepicy żył wrotnej i/lub wątrobowych. U 16 z tych chorych stwierdzono obecność żylaków przełyku. Ruksolitynib był dobrze tolerowany; toksyczność hematologiczna okazała się podobna do obserwowanej w grupie chorych bez zakrzepicy, nie obserwowano epizodów krwawienia. Po 24 tygodniach redukcję objętości śledziony o co najmniej $35 \% \mathrm{w}$ badaniu MRI stwierdzono u 6 z 21 chorych (29\%), zaś u $62 \%$ chorych (13/21) doszło do zmniejszenia o $50 \%$ rozmiarów śledziony w badaniu przedmiotowym [38].

\section{Ruksolitynib u chorych na MF}

o niższym stopniu zaawansowania

Badania rejestracyjne dotyczące ruksolitynibu COMFORT-I i COMFORT-II obejmowały chorych na MF o wyższym stopniu zaawansowania (IPSS pośrednie-2 i wysokie). Nie ma randomizowanych badań $z$ udziałem pacjentów $z$ MF cechujących się niższym ryzykiem choroby.

Badaniem JUMP, wieloośrodkowym, jednoramiennym badaniem fazy 3b, służącym ocenie skuteczności ruksolitynibu w grupie 1144 pacjentów, objęto 163 chorych $z$ IPSS pośrednim- 1 i śledzioną wyczuwalną co najmniej $5 \mathrm{~cm}$ poniżej lewego luku żebrowego [39]. W tej podgrupie u $61 \%$ chorych po 48 tygodniach i u $77 \%$ po 72 tygodniach stwierdzano co najmniej 50-procentowe zmniejszenie śledziony w badaniu palpacyjnym. Zmniejszenie objawów ogólnych obserwowano u 30-40\% pacjentów. Należy podkreślić, że dopuszczalna liczba PLT u pacjentów włączanych do badania JUMP była niższa niż w badaniach COMFORT i wynosiła $50 \mathrm{G} / 1$. Toksyczność była podobna do stwierdzanej w badaniach COMFORT. U 54\% pacjentów obserwowano niedokrwistość (u 24,5\% 3.-4. stopnia), zaś u 40,5\% - małopłytkowość (3.-4. stopnia u $11 \%)$. U $11 \%$ chorych objawy niepożądane były powodem zaprzestania leczenia.

Do badania ROBUST (badanie II fazy prowadzone w Wielkiej Brytanii) zakwalifikowano 48 pacjentów, 14 spośród nich $z$ IPSS pośrednim-1 [40]. W tej grupie u $8(57,1 \%)$ pacjentów obserwowano co najmniej 50-procentową redukcję rozmiarów śledziony - zarówno w 24., jak i w 48. tygodniu, natomiast u 3 chorych $(21,4 \%)$ stwierdzono zmniejszenie objawów ogólnych o ponad $50 \%$ w skali MPN-SAF TSS.

Guglielmelli i wsp. [35] przeprowadzili analizę wpływu mutacji na skuteczność ruksolitynibu w grupie 166 chorych w badaniu COMFORT-II. Stwierdzili oni, że obecność mutacji nie wpływa na skuteczność leczenia (zmniejszenie splenomegalii i objawów ogólnych), a także nie zwiększa częstości występowania hematologicznych objawów niepożądanych - niedokrwistości i małopłytkowości. Korzystny wpływ ruksolitynibu na OS nie zależał od obecności źle rokujących mutacji $A S X L 1$, EZH2, SRSF2, IDH1/2, ale należy podkreślić, że ich obecność istotnie skracała czas trwania odpowiedzi na leczenie. $Z$ tego względu w grupie chorych $z$ obecnością mutacji kwalifikujących się do przeszczepienia allogenicznych krwiotwórczych komórek macierzystych (allo-HSCT, allogeneic stem 
cell transplantation) nie należy odraczać decyzji o transplantacji, a leczenie ruksolitynibem powinno być jedynie terapią przygotowującą do zabiegu [35].

Zaprojektowano wieloośrodkowe, randomizowane badanie III fazy ReTHINK (NCT02598297), w którym chorzy na MF niższego ryzyka i z obecnością mutacji kwalifikujących ich do grupy HMR będą otrzymywali ruksolitynib lub placebo [41]. Celem badania jest określenie wpływu leku na przebieg kliniczny choroby.

W zaleceniach ELN-SIE (European Leukemia Net-Italian Society of Hematology) dopuszcza się zastosowanie ruksolitynibu u pacjentów z MF cechujących się ryzykiem pośrednim-1, jeśli występuje duża i/lub symptomatyczna splenomegalia ( $\geq 15 \mathrm{~cm}$ poniżej lewego łuku żebrowego), zwłaszcza w przypadku nieskuteczności hydroksymocznika i interferonu, a także $\mathrm{u}$ chorych $\mathrm{z}$ bardzo nasilonymi objawami ogólnymi ( $\geq 44$ wg skali MPN-SAF TSS) [31]. Ruksolitynib jest szczególnie zalecany w przypadku takich objawów, jak świąd skóry, utrata masy ciała i gorączka. Eksperci zwracają uwagę na toksyczność hematologiczną ruksolitynibu i brak danych na temat odległych objawów niepożądanych jego stosowania.

\section{Działania niepożądane}

Najczęstszymi hematologicznymi działaniami niepożądanymi $\mathrm{w}$ trakcie leczenia ruksolitynibem są niedokrwistość i małopłytkowość. Zależą one od dawki i wynikają $z$ blokady sygnału pochodzącego z przyłączenia EPO i TPO do receptora [22, 27]. W badaniach COMFORT-I i COMFORT-II niedokrwistość wszystkich stopni według Powszechnych Kryteriów Stopniowania Toksyczności (CTCAE, Common Terminology Criteria of Adverse Events) występowała u niemal wszystkich chorych leczonych ruksolitynibem, natomiast w stopniach 3. i 4. u odpowiednio $45,2 \%$ (COMFORT-I) i $62 \%$ (COMFORT-II) chorych. Niedokrwistość najczęściej pojawia się w pierwszych 8 tygodniach leczenia, osiagając nadir między 8. a 12. tygodniem, a następnie $\mathrm{u}$ większości chorych stężenie hemoglobiny ulega stopniowej poprawie i stabilizuje się na poziomie niższym niż wyjściowy po około 6 miesiącach terapii. Ponad połowa chorych wymagała przetoczenia koncentratu krwinek czerwonych (kkcz). W obu badaniach COMFORT u 1 chorego przerwano leczenie ruksolitynibem $z$ powodu niedokrwistości $(0,3 \%)$. Anemia nie pogarszała skuteczności tego leku ani w zakresie zmniejszenia śledziony, ani objawów ogólnych [22, 27]. W praktyce klinicznej niedokrwistość w trakcie leczenia ruksolitynibem zazwyczaj nie wymaga modyfikacji dawki ani przerwania leczenia, choć chorzy mogą wymagać przetoczeń kkcz. Zawsze należy wykluczyć inne przyczyny niedokrwistości i różnicować jej pogłębienie $z$ progresją choroby podstawowej, co może się objawiać powrotem/utrzymywaniem się objawów ogólnych.

W badaniach III fazy małopłytkowość w jakimkolwiek stopniu według CTCAE wystąpiła u około $70 \%$ chorych, zaś w stopniach 3 . i 4. dotyczyła $11 \%$ pacjentów leczonych inhibitorem JAK2 [22, 27]. Mediana czasu do jej wystąpienia wyniosła około 8 tygodni. Małopłytkowość była odwracalna po zmniejszeniu dawki lub przerwaniu podawania leku, a mediana czasu do wzrostu liczby PLT ponad $50 \mathrm{G} / 1$ wyniosła około 2 tygodnie [2]. Małopłytkowość wymaga modyfikacji dawkowania ruksolitynibu w celu unikania przerw w leczeniu, co mogłoby pogorszyć jego skuteczność. Dawkę początkową i jej modyfikacje ustala się na podstawie liczby PLT. U pacjentów $z$ liczbą PLT ponad $200 \mathrm{G} / 1$ wskazane jest stosowanie leku w dawce $20 \mathrm{mg} 2 \mathrm{razy} /$ dobę, Zalecana dawka początkowa $u$ chorych $z$ liczbą PLT 100-200 G/L wynosi $15 \mathrm{mg} 2$ razy/dobę, a z PLT 50-100 G/1 - 5 mg 2 razy/dobę. U pacjentów $z$ liczbą PLT poniżej $50 \mathrm{G} / 1$ terapia ruksolitynibem nie jest wskazana. Leczenie należy przerwać również w przypadku neutropenii poniżej 0,5 G/1 [2]. Wahania liczby PLT w trakcie leczenia wymagają dostosowania dawki według powyższego schematu.

Najczęstszymi powikłaniami krwotocznymi były wylewy podskórne, które dotyczyły $21 \%$ chorych. Krwawienia $z$ przewodu pokarmowego wszystkich stopni występowały $z$ częstością $5 \%$, w stopniach 3. i 4. - 1,3\%. Krwawienie śródczaszkowe stwierdzono u $1 \%$ chorych. Inne krwawienia (w tym $z$ nosa, po zabiegach i krwiomocz) we wszystkich stopniach wystąpiły u $13 \%$ chorych, zaś u 2,3\% chorych w stopniach 3. i 4. [22, 27].

Dane pochodzące $z$ opisów przypadków pacjentów wskazują, że również chorzy z liczbą PLT poniżej 50 G/l mogą odnosić korzyść $z$ terapii ruksolitynibem. Obserwowano chorych, u których po początkowym zmniejszeniu liczby PLT nawet do wartości mniejszej niż $10 \mathrm{G} / 1$ dochodziło do jej wzrostu powyżej wartości wyjściowych. Dotyczyło to zwłaszcza pacjentów $z$ istotnym zmniejszeniem rozmiarów śledziony $\mathrm{w}$ trakcie terapii ruksolitynibem. Zwiększenie liczby PLT w tej grupie chorych można tłumaczyć zmniejszeniem ich sekwestracji w śledzionie. Ponadto na wzrost ten mogą wpływać zmniejszona produkcja cytokin, lepsze funkcjonowanie mikrośrodowiska szpiku, a także zahamowanie funkcji makrofagów [42, 43].

Oprócz krwawień do niehematologicznych działań niepożądanych ruksolitynibu należą bóle i zawroty głowy (u ok. $15 \%$ chorych), w większości o lagodnym nasileniu [22]. Najczęstszymi działaniami 
niepożądanymi dotyczącymi przewodu pokarmowego są biegunki (23\% we wszystkich stopniach, 1-2\% w stopniach 3. i 4.) $[22,27]$. Ponadto u około $20 \%$ chorych obserwuje się lagodny do umiarkowanego wzrost aktywności aminotransferazy alaninowej (AlAT, alanine aminotransferase) i aminotransferazy asparaginianowej (AspAT, aspartate aminotransferase) [2].

Należy pamiętać, że w przypadku nagłego odstawienia ruksolitynibu może dojść do zespołu uwalniania cytokin o bardzo gwałtownym przebiegu, dlatego zaleca się stopniowe zmniejszanie dawki leku. Po odstawieniu leku szybko dochodzi do ponownego pojawienia się objawów ogólnych i powiększenia śledziony [22].

Poprzez działanie hamujące uwalnianie cytokin prozapalnych ruksolitynib działa immunosupresyjnie [19]. Ponadto upośledza działanie komórek dendrytycznych, prowadząc do dysfunkcji limfocytów T CD4+ i CD8+ zarówno in vitro, jak i in vivo [44]. Wskutek tego w trakcie leczenia chorzy są narażeni na infekcje, również oportunistyczne. W badaniach COMFORT obserwowano zwiększoną częstość zakażeń układu moczowego i infekcji o etiologii Herpes zoster [22, 27]. W literaturze opisywano również przypadki reaktywacji wirusa zapalenia wątroby typu B (HBV, hepatitis B virus) [45] czy gruźlicy [46, 47]. Opisywano także zapalenie pluc o etiologii Cryptococcus neoformans, toksoplazmozowe zapalenie siatkówki i postępującą leukoencefalopatię wieloogniskową [48-50]. Przed włączeniem leczenia ruksolitynibem należy wykonać badania przesiewowe w kierunku gruźlicy i wirusów hepatotropowych, a w przypadku dodatnich testów stosować odpowiednią profilaktykę. Nie ma zaleceń dotyczących stosowania profilaktyki przeciwinfekcyjnej u wszystkich pacjentów.

We włoskiej metaanalizie Lussana i wsp. [51] oceniono ryzyko infekcji u 2585 chorych leczonych ruksolitynibem. Analizowano łącznie 11 badań randomizowanych III i IV fazy oraz 28 opisów przypadków. W trzech badaniach ruksolitynib powodował zwiększone ryzyko infekcji Herpes zoster w porównaniu $z$ grupami kontrolnymi (iloraz szans [OR, odds ratio] 7,39 [1,33; 41,07]). W badaniach IV fazy najczęściej stwierdzano infekcje Herpes zoster (8\%), zapalenie oskrzeli $(6,1 \%)$ i zakażenia układu moczowego (6\%). Opisy przypadków dotyczyły reaktywacji/zakażenia gruźlicą (10 chorych), reaktywacji HBV (5 chorych) i infekcji Pneumocystis jiroveci (2 chorych) [51].

\section{Rola ruksolitynibu}

w przygotowaniu do allo-HSCT

Ruksolitynib można stosować w trakcie przygotowania chorych na MF do allo-HSCT. Redukcja stężenia cytokin prozapalnych i nasilenia objawów ogólnych, zmniejszenie śledziony i poprawa stanu ogólnego przed allo-HSCT mogą się przyczynić do zmniejszenia śmiertelności zależnej od transplantacji (TRM, transplant-related mortality) i poprawy wyników allo-HSCT [52]. Przed zastosowaniem ruksolitynibu przed allo-HSCT należy zawsze rozważyć ryzyko związane $z$ działaniami niepożądanymi leku, przede wszystkim takimi jak cytopenie, zwiększone ryzyko infekcji oportunistycznych czy objawy związane $z$ odstawieniem [52].

Dotychczas nie przeprowadzono randomizowanych badań, w których porównano by skuteczność terapii farmakologicznej inhibitorami kinazy JAK1/2 z allo-HSCT u pacjentów z IPSS/Dynamic IPSS (DIPSS) pośrednim-2 i wysokim. Na konferencji ASH (American Society of Haematology) w 2016 roku Masarowa i wsp. [53] przedstawili retrospektywną analizę porównującą wyniki leczenia chorych allo-HSCT $(\mathrm{n}=49)$ i inhibitorem JAK1/2 $(\mathrm{n}=41)$. Mediana OS w obu grupach nie różniła się istotnie i wynosiła 46 miesięcy po allo-HSCT i 42 miesiące w przypadku terapii inhibitorem JAK1/2 $(\mathrm{p}=0,30)$. Iloraz szans wynosił $69 \%$ i $80 \%$ po roku, $63 \%$ i $51 \%$ po 3 latach i $49 \%$ i $36 \%$ po 5 latach, odpowiednio, u chorych leczonych allo-HSCT i farmakologicznie [53].

$\mathrm{W}$ innej analizie retrospektywnej obejmującej 90 pacjentów $z$ MF, u których stosowano ruksolitynib przed allo-HSCT, wykazano korzystny wpływ leku, przede wszystkim u chorych $z$ poprawą kliniczną w trakcie terapii inhibitorem JAK [54]. Tylko u 8 pacjentów obserwowano działania niepożądane po odstawieniu leku (u 2 chorych spowodowały one odroczenie allo-HSCT). Objawy występowały częściej, gdy stosowanie ruksolitynibu przerwano wcześniej niż 6 dni przed rozpoczęciem kondycjonowania [54].

W badaniu Jaekel i wsp. [55] ruksolitynib stosowano u 14 pacjentów przed allo-HSCT. Mediana czasu terapii wynosiła 6,5 miesiąca. U 70\% chorych obserwowano poprawę w zakresie objawów ogólnych, u $60 \%$ zaś - zmniejszenie rozmiarów śledziony. Nie obserwowano objawów niepożądanych po odstawieniu leku. U 93\% pacjentów uzyskano wszczep, ostra postać choroby przeszczep przeciw gospodarzowi (aGvHD, acute graft versus host disease) wystąpiła u $14 \%$ chorych. Mediana obserwacji wynosiła 9 miesięcy, a OS, przeżycie wolne od zdarzeń (EFS, event-free survival) i TRM wynosiły, odpowiednio, 78,6\%, 64\% i 7\% [55]. Stübig i wsp. [56] stosowali ruksolitynib u 22 pacjentów z MF przed allo-HSCT. Również w tym badaniu nie obserwowano objawów odstawienia ruksolitynibu, 
u wszystkich chorych doszło do wszczepienia graftu, a aGvHD w stopniach nasilenia 3. i 4. według Światowej Organizacji Zdrowia (WHO, World Health Organization) wystąpiła u $24 \%$ chorych. Po roku obserwacji OS i DFS wyniosły $81 \%$ i $76 \%$ [56]. Natomiast prospektywne, wieloośrodkowe badanie akademickie II fazy, służące ocenie zastosowania ruksolitynibu przed allo-HSCT, przerwano po włączeniu 22 chorych ze względu na przypadki ciężkich powikłań, takich jak wstrząs kardiogenny, zespół lizy guza, posocznica, aGvHD [57].

Zgodnie $z$ zaleceniami ELN oraz EBMT (European Group for Blood and Marrow Transplantation) leczenie ruksolitynibem należy rozpocząć przynajmniej 2 miesiące przed planowaną transplantacją, następnie stopniowo zmniejszać dawkę leku 5-7 dni przed kondycjonowaniem i odstawić w dniu poprzedzającym kondycjonowanie [58].

\section{Piśmiennictwo}

1. Incyte Corporation. Jakafi (ruxolitinib) tablets [prescribing information]. http://www ema europa eu/ema/index jsp?curl=pages/ /medicines/human/medicines/002464/human_med_001568 jsp\&mid=WC0b01ac058001d124 2014 (12.06.2018).

2. Novartis Pharma GmbH. Jakavi Charakterystyka Produktu Leczniczego. http://www ema europa eu/ema/index jsp?curl=pages/ /medicines/human/medicines/002464/human_med_001568 jsp\&mid=WC0b01ac058001d124 2012 (12.06.2018).

3. Emanuel RM, Dueck AC, Geyer HL, et al. Myeloproliferative neoplasm (MPN) symptom assessment form total symptom score: prospective international assessment of an abbreviated symptom burden scoring system among patients with MPNs. J Clin Oncol. 2012; 30(33): 4098-4103, doi: 10.1200/JCO.2012.42.3863, indexed in Pubmed: 23071245.

4. Kuter DJ, Bain B, Mufti G, et al. Bone marrow fibrosis: pathophysiology and clinical significance of increased bone marrow stromal fibres. Br J Haematol. 2007; 139(3): 351-362, doi: 10.1111/j.13652141.2007.06807.x, indexed in Pubmed: 17910625.

5. Rampal R, Al-Shahrour F, Abdel-Wahab O, et al. Integrated genomic analysis illustrates the central role of JAK-STAT pathway activation in myeloproliferative neoplasm pathogenesis. Blood. 2014; 123(22): e123-e133, doi: 10.1182/blood-2014-02-554634, indexed in Pubmed: 24740812.

6. Campbell PJ, Scott LM, Baxter EJ, et al. Cancer Genome Project. Acquired mutation of the tyrosine kinase JAK2 in human myeloproliferative disorders. Lancet. 2005; 365(9464): 1054-1061, doi: 10.1016/S0140-6736(05)71142-9, indexed in Pubmed: 15781101.

7. Pikman Y, Lee BH, Mercher T, et al. MPLW515L is a novel somatic activating mutation in myelofibrosis with myeloid metaplasia. PLoS Med. 2006; 3(7): e270, doi: 10.1371/journal.pmed.0030270, indexed in Pubmed: 16834459.

8. Nangalia J, Massie CE, Baxter EJ, et al. Somatic CALR mutations in myeloproliferative neoplasms with nonmutated JAK2. N Engl J Med. 2013; 369(25): 2391-2405, doi: 10.1056/NEJMoa1312542, indexed in Pubmed: 24325359.
9. Tefferi A, Wassie EA, Lasho TL, et al. CALR vs JAK2 vs MPL-mutated or triple-negative myelofibrosis: clinical, cytogenetic and molecular comparisons. Leukemia. 2014; 28(7): 1472-1477, doi: 10.1038/leu.2014.3, indexed in Pubmed: 24402162.

10. Funakoshi-Tago M, Pelletier S, Matsuda T, et al. The Janus protein tyrosine kinase family and its role in cytokine signaling. Adv Immunol. 1995; 60(52): 1-35, indexed in Pubmed: 8607368.

11. Tefferi A, Guglielmelli P, Lasho TL, et al. CALR and ASXL1 mutations-based molecular prognostication in primary myelofibrosis: an international study of 570 patients. Leukemia. 2014; 28(7): 1494-1500, doi: 10.1038/leu.2014.57, indexed in Pubmed: 24496303.

12. Huang LJ, Constantinescu SN, Lodish HF. The N-terminal domain of Janus kinase 2 is required for Golgi processing and cell surface expression of erythropoietin receptor. Mol Cell. 2001; 8(6): 1327-1338, indexed in Pubmed: 11779507.

13. Toms AV, Deshpande A, McNally R, et al. Structure of a pseudokinase-domain switch that controls oncogenic activation of Jak kinases. Nat Struct Mol Biol. 2013; 20(10): 1221-1223, doi: 10.1038/nsmb.2673, indexed in Pubmed: 24013208.

14. Leroy E, Constantinescu SN, Leroy E, et al. Rethinking JAK2 inhibition: towards novel strategies of more specific and versatile Janus kinase inhibition. Leukemia. 2017; 31(5): 1023-1038, doi: 10.1038/leu.2017.43, indexed in Pubmed: 28119526.

15. Koppikar P, Bhagwat N, Kilpivaara O, et al. Heterodimeric JAK-STAT activation as a mechanism of persistence to JAK2 inhibitor therapy. Nature. 2012; 489(7414): 155-159, doi: 10.1038/ /nature11303, indexed in Pubmed: 22820254.

16. Bhagwat N, Levine RL, Koppikar P. Sensitivity and resistance of JAK2 inhibitors to myeloproliferative neoplasms. Int J Hematol. 2013; 97(6): 695-702, doi: 10.1007/s12185-013-1353-5., indexed in Pubmed: 23670175.

17. Shi JG, Chen X, McGee RF, et al. The pharmacokinetics, pharmacodynamics, and safety of orally dosed INCB018424 phosphate in healthy volunteers. J Clin Pharmacol. 2011; 51(12): 1644-1654, doi: 10.1177/0091270010389469, indexed in Pubmed: 21257798.

18. Shi JG, Chen X, Emm T, et al. The effect of CYP3A4 inhibition or induction on the pharmacokinetics and pharmacodynamics of orally administered ruxolitinib (INCB018424 phosphate) in healthy volunteers. J Clin Pharmacol. 2012; 52(6): 809-818, doi: 10.1177/0091270011405663, indexed in Pubmed: 21602517.

19. Verstovsek S, Mesa RA, Gotlib J, et al. COMFORT-I Investigators, COMFORT Investigators. Safety and efficacy of INCB018424, a JAK1 and JAK2 inhibitor, in myelofibrosis. N Engl J Med. 2010; 363(12): 1117-1127, doi: 10.1056/NEJMoa1002028, indexed in Pubmed: 20843246.

20. Kvasnicka HM, Thiele J, Bueso-Ramos C. Effects of five-years of ruxolitinib therapy on bone marrow morphology in patients with myelofibrosis and comparison with best available therapy. Blood. 2013; 122: 4055.

21. Kvasnicka HM, Thiele J, Bueso-Ramos CE, et al. Long-term effects of ruxolitinib versus best available therapy on bone marrow fibrosis in patients with myelofibrosis. J Hematol Oncol. 2018; 11(1): 42, doi: 10.1186/s13045-018-0585-5, indexed in Pubmed: 29544547.

22. Verstovsek S, Mesa RA, Gotlib J, et al. COMFORT-I investigators. A double-blind, placebo-controlled trial of ruxolitinib for myelofibrosis. N Engl J Med. 2012; 366(9): 799-807, doi: 10.1056/ /NEJMoa1110557, indexed in Pubmed: 22375971.

23. Tefferi A, Barosi G, Mesa RA, et al. IWG for Myelofibrosis Research and Treatment (IWG-MRT). International Working Group 
(IWG) consensus criteria for treatment response in myelofibrosis with myeloid metaplasia, for the IWG for Myelofibrosis Research and Treatment (IWG-MRT). Blood. 2006; 108(5): 1497-1503, doi: 10.1182/blood-2006-03-009746, indexed in Pubmed: 16675707 .

24. Verstovsek S, Mesa RA, Gotlib J, et al. Efficacy, safety and survival with ruxolitinib in patients with myelofibrosis: results of a median 2-year follow-up of COMFORT-I. Haematologica. 2013; 98(12): 1865-1871, doi: 10.3324/haematol.2013.092155, indexed in Pubmed: 24038026.

25. Mesa RA, Gotlib J, Gupta V, et al. Effect of ruxolitinib therapy on myelofibrosis-related symptoms and other patient-reported outcomes in COMFORT-I: a randomized, double-blind, placebo-controlled trial. J Clin Oncol. 2013; 31(10): 1285-1292, doi: 10.1200/ JJCO.2012.44.4489, indexed in Pubmed: 23423753.

26. Verstovsek S, Mesa RA, Gotlib J, et al. The clinical benefit of ruxolitinib across patient subgroups: analysis of a placebo-controlled, Phase III study in patients with myelofibrosis. Br J Haematol. 2013; 161(4): 508-516, doi: 10.1111/bjh.12274, indexed in Pubmed: 23480528.

27. Harrison C, Kiladjian JJ, Al-Ali HK, et al. JAK inhibition with ruxolitinib versus best available therapy for myelofibrosis. $\mathrm{N}$ Engl J Med. 2012; 366(9): 787-798, doi: 10.1056/NEJMoa1110556, indexed in Pubmed: 22375970.

28. Harrison CN, Mesa RA, Kiladjian JJ, et al. Health-related quality of life and symptoms in patients with myelofibrosis treated with ruxolitinib versus best available therapy. Br J Haematol. 2013; 162(2): 229-239, doi: 10.1111/bjh.12375, indexed in Pubmed: 23672349 .

29. Cervantes F, Vannucchi AM, Kiladjian JJ, et al. COMFORT-II investigators. Three-year efficacy, safety, and survival findings from COMFORT-II, a phase 3 study comparing ruxolitinib with best available therapy for myelofibrosis. Blood. 2013; 122(25): 4047-4053, doi: 10.1182/blood-2013-02-485888, indexed in Pubmed: 24174625 .

30. Vannucchi AM, Kantarjian HM, Kiladjian JJ, et al. COMFORT Investigators. A pooled analysis of overall survival in COMFORT-I and COMFORT-II, 2 randomized phase III trials of ruxolitinib for the treatment of myelofibrosis. Haematologica. 2015; 100(9): 1139-1145, doi: 10.3324/haematol.2014.119545, indexed in Pubmed: 26069290.

31. Marchetti M, Barosi G, Cervantes F, et al. Which patients with myelofibrosis should receive ruxolitinib therapy? ELN-SIE evidence-based recommendations. Leukemia. 2017; 31(4): 882-888, doi: 10.1038/leu.2016.283, indexed in Pubmed: 27740634.

32. Martí-Carvajal AJ, Anand V, Solà I. Janus kinase-1 and Janus kinase-2 inhibitors for treating myelofibrosis. Cochrane Database Syst Rev. 2015(4): CD010298, doi: 10.1002/14651858.CD010298. pub2, indexed in Pubmed: 25860512.

33. Barosi G, Rosti V, Gale RP. Critical appraisal of the role of ruxolitinib in myeloproliferative neoplasm-associated myelofibrosis. Onco Targets Ther. 2015; 8: 1091-1102, doi: 10.2147/OTT. S31916, indexed in Pubmed: 26056473.

34. Cervantes F, Pereira A. Does ruxolitinib prolong the survival of patients with myelofibrosis? Blood. 2017; 129(7): 832-837, doi: 10.1182/blood-2016-11-731604, indexed in Pubmed: 28031182.

35. Guglielmelli P, Biamonte F, Rotunno G, et al. COMFORT-II Investigators, Associazione Italiana per la Ricerca sul Cancro Gruppo Italiano Malattie Mieloproliferative (AGIMM) Investigators. Impact of mutational status on outcomes in myelofibrosis patients treated with ruxolitinib in the COMFORT-II study. Blood. 2014; 123(14): 2157-2160, doi: 10.1182/blood-2013-11-536557, indexed in Pubmed: 24458439.

36. Passamonti F, Caramazza D, Maffioli M. JAK inhibitor in CALR-mutant myelofibrosis. N Engl J Med. 2014; 370(12): 1168-1169, doi: 10.1056/NEJMc1400499, indexed in Pubmed: 24645956.

37. Palandri F, Palumbo GA, Bonifacio M, et al. Baseline factors associated with response to ruxolitinib: an independent study on 408 patients with myelofibrosis. Oncotarget. 2017; 8(45): 79073-79086, doi: 10.18632/oncotarget.18674, indexed in Pubmed: 29108288.

38. Pieri L, Paoli C, Arena U, et al. Safety and efficacy of ruxolitinib in splanchnic vein thrombosis associated with myeloproliferative neoplasms. Am J Hematol. 2017; 92(2): 187-195, doi: 10.1002/ /ajh.24614, indexed in Pubmed: 27880982.

39. Al-Ali HK, Griesshammer M, le Coutre P, et al. Safety and efficacy of ruxolitinib in an open-label, multicenter, single-arm phase $3 \mathrm{~b}$ expanded-access study in patients with myelofibrosis: a snapshot of 1144 patients in the JUMP trial. Haematologica. 2016; 101(9): 1065-1073, doi: 10.3324/haematol.2016.143677, indexed in Pubmed: 27247324.

40. Mead AJ, Milojkovic D, Knapper S, et al. Response to ruxolitinib in patients with intermediate-1-, intermediate-2-, and high-risk myelofibrosis: results of the UK ROBUST Trial. Br J Haematol. 2015; 170(1): 29-39, doi: 10.1111/bjh.13379, indexed in Pubmed: 25824940.

41. Lancman G, Mascarenhas J. Should we be treating lower risk myelofibrosis patients with a JAK2 inhibitor? Expert Rev Hematol. 2017; 10(1): 23-28, doi: 10.1080/17474086.2017.126426, indexed in Pubmed: 27882812.

42. Bjørn ME, Holmström MO, Hasselbalch HC. Ruxolitinib is manageable in patients with myelofibrosis and severe thrombocytopenia: a report on 12 Danish patients. Leuk Lymphoma. 2016; 57(1): 125-128, doi: 10.3109/10428194.2015.1046867, indexed in Pubmed: 25936872.

43. Grunwald MR, Spivak JL. Ruxolitinib enhances platelet production in patients with thrombocytopenic myelofibrosis. J Clin Oncol. 2016; 34(5): e38-e40, doi: 10.1200/JC0.2013.51.0057, indexed in Pubmed: 24958831.

44. Heine A, Held SA, Daecke SN, et al. The JAK-inhibitor ruxolitinib impairs dendritic cell function in vitro and in vivo. Blood. 2013; 122(7): 1192-1202, doi: 10.1182/blood-2013-03-484642, indexed in Pubmed: 23770777.

45. Caocci G, Murgia F, Podda L, et al. Reactivation of hepatitis B virus infection following ruxolitinib treatment in a patient with myelofibrosis. Leukemia. 2014; 28(1): 225-227, doi: 10.1038/ /leu.2013.235, indexed in Pubmed: 23929216.

46. Colomba C, Rubino R, Siracusa L, et al. Disseminated tuberculosis in a patient treated with a JAK2 selective inhibitor: a case report. BMC Res Notes. 2012; 5: 552, doi: 10.1186/1756-0500-5552, indexed in Pubmed: 23039051.

47. Hopman RK, Lawrence SJ, Oh ST. Disseminated tuberculosis associated with ruxolitinib. Leukemia. 2014; 28(8): 1750-1751, doi: 10.1038/leu.2014.104, indexed in Pubmed: 24625550.

48. Wysham NG, Sullivan DR, Allada G. An opportunistic infection associated with ruxolitinib, a novel janus kinase 1,2 inhibitor. Chest. 2013; 143(5): 1478-1479, doi: 10.1378/chest.12-1604, indexed in Pubmed: 23648912.

49. Goldberg RA, Reichel E, Oshry LJ. Bilateral toxoplasmosis retinitis associated with ruxolitinib. N Engl J Med. 2013; 369(7): 681-683, doi: 10.1056/NEJMc1302895, indexed in Pubmed: 23944322. 
50. Wathes R, Moule S, Milojkovic D. Progressive multifocal leukoencephalopathy associated with ruxolitinib. N Engl J Med. 2013; 369(2): 197-198, doi: 10.1056/NEJMc1302135, indexed in Pubmed: 23841743.

51. Lussana F, Cattaneo M, Rambaldi A, et al. Ruxolitinib-associated infections: A systematic review and meta-analysis. Am J Hematol. 2018; 93(3): 339-347, doi: 10.1002/ajh.24976, indexed in Pubmed: 29150886.

52. Gupta V, Gotlib J, Radich JP, et al. Janus kinase inhibitors and allogeneic stem cell transplantation for myelofibrosis. Biol Blood Marrow Transplant. 2014; 20(9): 1274-1281, doi: 10.1016/j. bbmt.2014.03.017, indexed in Pubmed: 24680977.

53. Masarova L, Popat UR, Bose P, et al. Allogeneic stem cell transplantation versus medical therapy in patients with advanced myelofibrosis: matched survival analysis and the effect of JAK2 inhibitor therapy. Blood. 2016; 128: 4687.

54. Shanavas M, Popat U, Michaelis LC, et al. Outcomes of allogeneic hematopoietic cell transplantation in patients with myelofibrosis with prior exposure to Janus kinase 1/2 Inhibitors. Biol Blood Marrow Transplant. 2016; 22(3): 432-440, doi: 10.1016/j. bbmt.2015.10.005, indexed in Pubmed: 26493563.
55. Jaekel N, Behre G, Behning A, et al. Allogeneic hematopoietic cell transplantation for myelofibrosis in patients pretreated with the JAK1 and JAK2 inhibitor ruxolitinib. Bone Marrow Transplant. 2014; 49(2): 179-184, doi: 10.1038/bmt.2013.173, indexed in Pubmed: 24292520.

56. Stübig T, Alchalby H, Ditschkowski M, et al. JAK inhibition with ruxolitinib as pretreatment for allogeneic stem cell transplantation in primary or post-ET/PV myelofibrosis. Leukemia. 2014; 28(8): 1736-1738, doi: 10.1038/leu.2014.86, indexed in Pubmed: 24569777.

57. Kröger N, Giorgino T, Scott BL, et al. Impact of allogeneic stem cell transplantation on survival of patients less than 65 years of age with primary myelofibrosis. Blood. 2015; 125(21): 3347-50; quiz 3364, doi: 10.1182/blood-2014-10-608315, indexed in Pubmed: 25784679 .

58. Kröger NM, Deeg JH, Olavarria E, et al. Indication and management of allogeneic stem cell transplantation in primary myelofibrosis: a consensus process by an EBMT/ELN international working group. Leukemia. 2015; 29(11): 2126-2133, doi: 10.1038/ /leu.2015.233, indexed in Pubmed: 26293647. 